\title{
Peningkatkan Kemampuan Bernyanyi Sesuai Nada Dengan Menggunakan Alat Peraga Buret Di Taman Kanak- Kanak Negeri Pembina Kabupaten Sragen
}

\author{
Yustina Laurentius Sri Mulatsih39 \\ mulatsih@gmail.com
}

\begin{abstract}
This research aims to know students' singing skill in proper tone taught by buret in State Kindergarten School of Pembina Sragen. Buret was a music instrument created using bamboo and arraged following the music tone. This is an action research conducted in even semester of 2016/2017academic year in two cycles. By using technique of singing with buret, students can sing properly by following the buret tone. The result of this research were (1) students' was actively engaged to sing in proper tone and followed the teachers' instruction during learning, (2) the number of students who properly followed the tone was increase at the end of cycle 2. The media of buret is proven to be an alternative medium to teach how to sing in proper tone for kindergarten scool. Teachers were supposed to be mare creative to create other media to engange their students.
\end{abstract}

Keywords: Singing Skill, Tone, Music Instrumen, Buret,

39 Guru TK Negeri Pembina Sragen 


\section{PENDAHULUAN}

B idang pengembangan seni khususnya seni musik merupakan alat pendidikan utama bagi anakanak usia dini untuk melatih sensitifitas diri. Disamping itu, musik memiliki sifat yang menyenangkan sekaligus bermanfaat untuk mengembangkan fisik, intellegenci atau kecerdasan, emosi atau perasaan, etika, estetika, sosial dan kekayaan kosakata bahasa anak-anak. Seni musik merupakan media terbuka untuk menyampaikan pesan-pesan edukatif melalui tema yang ingin di kembangkan dalam pembentukan watak awal anak-anak (Prastiwi, 2008).

Salah satu unsur dari berbagai lingkup perkembangan, tidak kalah penting adalah lingkup perkembanngan seni. Anak-anak usia dini pada umumnya belum mampu berfikir abstrak, maka dalam pemilihan bahan pembelajaran seni musik, guru harus tahu dan memahami tingkat perkembangan fisik dan jiwa serta memiliki metode yang tepat serta praktis sehingga dapat mencapai sasaran yang diharapkan (Fadlullah, 2012). Kemampuan seni merupakan salah satu dari bidang pengembangan kemampuan dasar yang dipersiapkan oleh guru untuk meningkatkan kemampuan dan kreatifitas anak sesuai dengan tahap perkembangnnya (Yamin \& Sanan, 2013). Ada beberapa pembelajaran seni yang diajarkan kepada anak usia dini yaitu seni rupa, seni musik dan seni ketrampilan (Pekerti, dkk. 2010). Peragaanya pun dapat dilakukan dengan berbagai metode dan sudah barang tentu sesuai dengan prinsip belajar melalui bermain serta dalam suasana yang menyenangkan (Anitah, 2008).

Realita di lapangan dalam hal ini di Taman kanak-kanak Negeri Pembina Kabupaten Sragen banyak anak yang tidak berminat, tidak bergairah dan banyak anak yang bernyanyi tidak sesuai irama dan fals. Anak-anak dalam bernyanyi banyak yang asal-asalan dan monoton karena lagu yang dibawakan kebanyakan lagu anak yang sudah familiar. Apabila diberi pembelajaran lagu baru banyak anak yang tidak tertarik, dikarenakan banyak guru yang mengajar bernyanyi tidak memakai alat musik dan banyak juga guru yang menyanyi fals tidak sesuai nada, juga banyak guru yang tidak mengetahui cara bernyanyi dengan teknik yang benar, dan guru kurang mengetahui tentang tinggi rendah nada untuk anak.

Dalam pembelajaran bernyanyi sesuai nada untuk lagu baru banyak guru yang tidak berminat mengajarkan dengan alasan tidak berbakat bernyanyi, ataupun tidak bisa membaca notasi dengan benar. Padahal bernyanyi sangatlah penting bagi guru untuk penyampaian berbagai pesan moral untuk anak didik (Suyadi, 2010). Dari realita tersebut berdampak pembelajaran bernyanyi kurang diminati oleh guru maupun anak didik, apalagi menyampaikan lagu baru. Banyak terjadi di kelas waktu guru bernyanyi, anak gaduh sendiri tidak mau memperhatikan guru. Hal ini dikarenakan guru banyak yang tidak menggunakan fasilitas alat peraga dalam hal ini alat musik, sehingga target untuk mengembangkan anak dapat bernyanyi sesuai nada banyak yang belum tercapai. Dari permasalahan diatas penulis tertarik untuk menciptakan media instrument musik anak, sekaligus untuk bahan penelitian tindakan kelas khususnya bernyanyi sesuai nada menggunakan alat musik yang kemudian disebut Buret

Penanganan pendidikan anak usia dini membutuhkan kesungguhan hati dan ketepatan pemilihan bahan ajar yang sesuai dengan perkembangan fisik dan jiwa anak serta penerapan metode mengajar yang tepat sederhana, praktis, serta mudah dilakukan oleh anak (Hildayani, 2009). Seni musik sebagai bahan dari mata pelajaran kesenian ternyata memiliki unsur yang sangat berharga bagi perkembangan fisik, intelegensi, emosi, etika dan estetika, sosial serta perkembangan bahasa anak. Irama musik yang merupakan bagian dari ritme yang selalu berubah bentuk serta kecepatannya ternyata mampu meningkatkan perkembangan anak sebalum lahir, hingga remaja bahkan manusia menjadi tua. Unsur musik harmoni yang memiliki peran memperindah musik dalam pemilihannya dan penerapannya membutuhkan pemikiran yang jeli dan teliti, karena bila salah perhitungan matematisnya akan merusak musik itu sendiri. Seorang penyanyi yang handal tentu memiliki daya ingat sangat dibutuhkan oleh ilmuilmu sosial.

Pemilihan ritme dan jenis musik penting dalam pembelajaran seni (Ali, dkk, 2016). Musik yang cepat kadang-kadang melambat dapat meningkatkan emosi anak yang baru separuh dipahami dan membantu 
belajar mengekspresikan perasaannya. Musik sebagai media terbuka dan menyenangkan dapat dipergunakan untuk menyampaikan berbagai pesan-pesan pendidikan moral, agama, serta budi pekerti (Kemendiknas, 2010). Memainkan musik bersama-sama dengan orang lain dapat memperkuat ikatan dengan keluarga dan komunitasnya sekaligus mampu menghubungkan dengan warisan budaya yang melahirkan kesenian tersebut. Musik adalah alat pendidikan yang multiguna dan tepat guna serta menyenangkan khususnya bagi anak-anak usia dini (kemendikbud, 2015).

Dalam mengajarkan musik kepada anak harus juga melelui kegiatan bermain (Raharjo, 2006). Dengan bermain anak memperoleh kesempatan mengembangkan potensi-potensi yang ada padanya dan memberikan peluang bagi anak untuk berkembang seutuhnya, baik fisik, intelektual, bahasa dan perilakunya. Manfaat bermain bagi anak ialah merupakan proses belajar yang menyenangkan bagi anak karena bermain dapat membantu anak mengenal dunianya, mengembangkan konsep-konsep baru, mengambil resiko, meningkatkan keterampilan sosial anak dan dapat membentuk prilaku anak (Hurlock, 1995). Berpedoman pada Depdiknas (2006) permainan yang digunakan dalam kegiatan belajar mengajar di TK hendaknya memenuhi kriteria-kriteria sebagai berikut:

a. Permainan sesuai dengan tujuan dan fungsi penggunaannya, serta dapat memberikan pengertia atau menjelaskan suatu konsepterntu

b. Permainan dapat mendorng kreatifitas anak serta memberikan kesempatan kepada anak untuk bereksperimen dan bereksplorasi.

c. Permainan harus memenuhi unsur kebenaran ukuran ketlitian dan kejelasan dan tidak membahayakan anak, harus aman dan tidak menggunakan zat warna yang berbahaya bagi kesehatan anak.

d. Permainan hendaknya menarik, menyenangkan dan tidak membosankan, memenuhi unsure keindahan dalam bentuk maupun warna/kombinasinya warnanya rata, rapi dalam pembuatannya.

e. Permainan harus dapat digunakan baik guru maupun anak.

Berdasarkan pendapatan para ahli diatas maka saat memilih media musik dalam pembelajaran anak usia dini haruslah yang menyenangkan dan dapat dilakukan secara individual ataupun kelompok sehingga anak akan mendapatkan pengetahuan dalam permainan tersebut (Depdiknas, 2004). Jeis yang sering dipakai dan paling mudah digunakan ialah jenis alat musik perkusi. Instrumen perkusi pada dasarnya merupakan benda apapun yang dapat mengahasilkan suara baik karena dipukul, dikocok, digosok, diadukan, atau dengan cara apapun yang dapat membuat getaran pada benda tersebut. Istilah instrument perkusi biasanya digunakan pada benda yang digunakan sebagai pengiring dalam suatu permainan musik.

Buret merupakan alat peraga yang dimainkan dengan cara dipukul yang terbuat dari bambu, alat musik ini sangat mudah dibuat dan sangat mudah untuk mencari bahannya, apalagi di daerah pedesaan bambu sangat mudah kita cari. Buret cara pembuatannya mudah dan murah karena bahannya dari bahan bekas, akan tetapi cara pembuatannya memerlukan tenaga beberapa orang untuk menari karet, dan memegang bambunya. Buret adalah singkatan dari bambu dan karet karena alat musik ini di buat dari bambu yang disusun dan diikat karet, maka alat ini kami namai Buret.

Buret disusun dari bamboo yang sejajar dengan ukuran yang sama kemudian diberikan lubang agar menghasilkan bunyi. Urutan bunyi pada alat buret ini disusun berdasarkan tinggi nada yang dihasilkan. Selain mudah pembuatan Buret juga murah bahannya, karena bahannya dari bahan bekas sehingga hanya perlu sedikit kreatifitas dari guru itu sendiri

\section{METODE PENELITIAN}

Dalam penelitian ini pembelajaran seni terutama dalam kegiatan bernyanyi sesuai nada yang akan penulis teliti. Tujuan Penelitian ini adalah untuk mengetahui peningkatan kemampuan anak dalam 
menyanyi sesuai nada dengan menggunakan alat peraga Buret. Jenis penelitian yang digunakan yaitu Penelitian Tindakan Kelas (PTK). Penelitian ini dilakukan oleh peneliti dengan guru yang diajak berkolaborasi di dalam kelasnya sendiri melalui refleksi diri dengan tujuan untuk memperbaiki kinerjanya sebagai guru. Guru bertanggung jawab terhadap anak didiknya agar kemampuan dan hasil belajar anak menjadi meningkat sehingga penting melakukan refleksi. Penelitian yang dilakukan penulis mengambil lokasi di Taman Kanak-Kanak Negeri Pembina, Kabupaten Sragen yang terletak di Jalan Kenanga nomor 6 Beloran Sragen Waktu penelitian ini adalah di Taman Kanak-Kanak Negeri Pembina Kecamatan Sragen, Kabupaten Sragen semester dua (2) Tahun Pelajaran 2016/2017.

Subyek penelitian ini adalah siswa Taman Kanak-Kanak Negeri Pembina, Kabupaten Sragen pada kelompok B1 yang terdiri dari 8 anak perempuan dan 12 anak laki-laki, dan jumlah seluruhnya ada 20 anak. Fokus penelitian adalah pembelajaran meningkatkan kemampuan bernyanyi sesuai nada dengan menggunakan alat musik Buret. Dalam kegiatan pembelajaran ini focus kegiatan pengamatan ialah agar:

a. Memfokuskan dalam kegiatan bernyanyi dan menarik perhatian anak.

b. Menarik anak untuik bernyanyi sesuai nada

Setelah melakukan observasi awal kemudian penulis menyusun rencana tindakan perbaikan yang terdiri dari dua (2) siklus. Pelaksanaan perbaikan pembelajaran melalui Penelitian Tindakan Kelas (PTK) dilakukan saat kegiatan proses belajar mengajar berlangsung. Peneliti bersama teman sejawat memulai perbaikan pada setiap siklus yang terbagi menjadi tiga Rencana Kegiatan Harian (RKH) yaitu:

Tabel 1. Rencana Kegiatan harian Siklus I

\begin{tabular}{|l|l|}
\hline \multicolumn{1}{|c|}{ Siklus I } & Materi \\
\hline RKH I & Menyanyi lagu yang berjudul "Bintang Kejora" \\
RKH 2 & \\
RKH 3 & \\
\hline
\end{tabular}

Setelah siklus satu (I) dilaksanakan dan hasilnya belum sesuai target ketuntasan, maka peneliti menyusun Rencana Perbaikan pada siklus dua (II) yang terbagi tiga Rencana Kegiatan Harian (RKH) dengan materi sebagai berikut:

Tabel 2. Rencana Kegiatan harian Siklus II

\begin{tabular}{|l|l|}
\hline \multicolumn{1}{|c|}{ Siklus II } & \multicolumn{1}{|c|}{ Materi } \\
\hline RKH I & Menyanyi judul lagu Baru \\
RKH 2 & \\
\hline
\end{tabular}

\section{Observasi dan Evaluasi}

Dalam penelitian ini ada dua (2) teknik pengumpulan data yaitu observasi digunakan untuk mengamati indikator yang tampak selama proses pembelajaran dan pemberian tugas unjuk kerja untuk menilai capaian belajar siswa. Dalam kegiatan observasi dan evaluasi hal yang dijadikan indikator kerja meliputi penguasaan materi dan pemanfaatan dan penggunaan alat peraga oleh guru. Sedangkan pada diri siswa diamati keaktifan dan kemampuan anak dalam menyanyi bersama serta Kemampuan dan keberanian anak dalam menyanyi tunggal.

Menurut Mulyaso (2002) keberhasilan kelas untuk aspek seni dapat dilihat dari hasil evaluasi jika hasil belajar anak mencapai $65 \%$ secara individu dan secara klasikal sehingga nilai inilah yang penulis jadikan acuan perbaikan. 


\section{HASIL DAN PEMBAHASAN}

\section{Deskripsi Kondisi Awal}

Pada kegiatan awal anak pada penelitian ini adalah sebelum dilaksanakan perbaikan. Dalam kegiatan bernyanyi sesuai dengan nada, dari 20 jumlah anak di kelompok B1 Tk N Pembina Kabupaten Sragen, hanya 1 anak (5\%), yang dapat menyanyi sesuai dengan nada dengan lancar, baik dan sesuai dengan indikator yang telah ditentukan, sedangkan yang mempunyai kemampuan cukup ada 3 anak yang jika dipresentasekan yaitu 15\%. Dan anak ada 16 anak (80\%) yang belum memenuhi kriteria seperti yang ditunjukkan dalam gambar 1 . Hal itu diduga karena penggunaan metode yang kurang tepat.

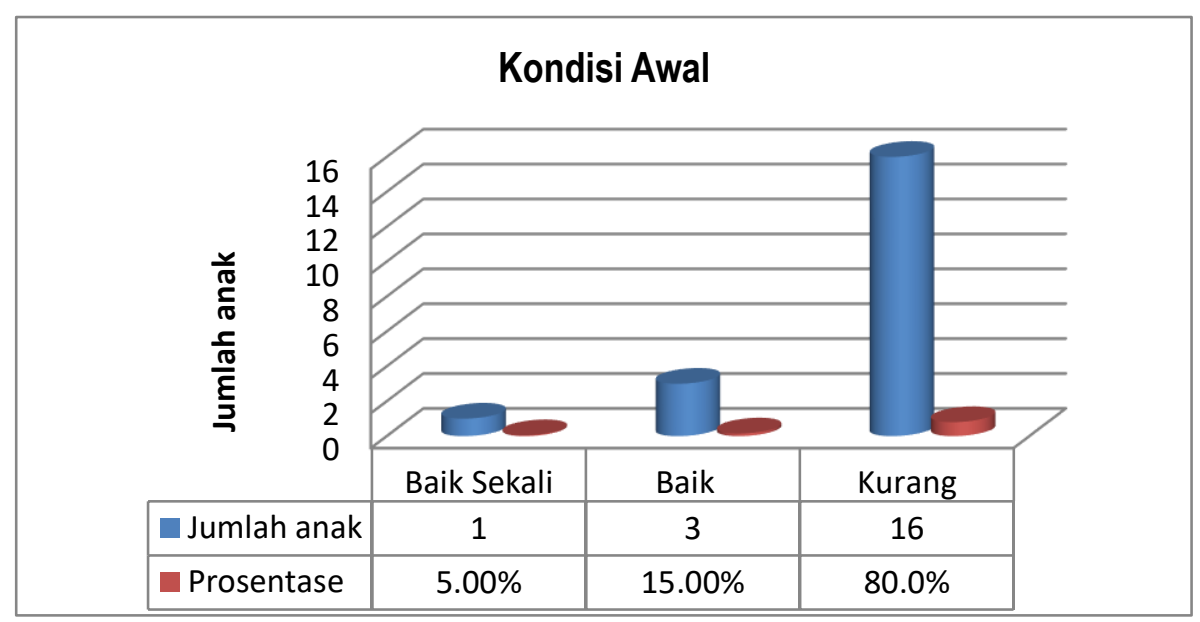

Diagram 1. Kondisi Awal Kemampuan Bernyanyi Sesuai Nada

\section{Siklus I}

Pada siklus ini perbaikan proses pembelajaan dilakukan pada pemilihan metode dengan memakaii tepuk tanagan untuk mengajak siswa aktif mengikuti nada. Dari hasil pengamatan guru terhadap proses kegiatan belajar mengajar tentang bernyanyi sesuai nada, ternyata bernyanyi sesuai nada dengan menggunakan tepuk tangan tidak dapat menghidupkan suasana dan minat belajar anak. Terlihat anak tidak antusias mengikutinya. Jadi belum banyak anak yang bisa bernyanyi sesuai nada. Dan kebanyakan masih belum berani bernyanyi maju kedepan.

Dari hasil observasi dan refleksi Siklus I (satu) hari pertama (1) disimpulkan bahwa pelaksanaan tindakan pada siklus I, belum berjalan lancar dan masih ada 16 anak yang kemampuan bernyanyinya masih kurang. Maka masih perlu motivasi saat pelaksanaan tindakan selanjutnya. Jadi pada pertemuan pertama (1) pada siklus I ini belum ada perubahan masih sama seperti kondisi awal.

Kemudan pada pertemuan kedua (2) diperkenalakan peraga buret. Dari hasil pengamatan terhadap proses kegiatan belajar mengajar ternyata dalam bernyanyi sesuai nada melalui alat musik Buret dapat menghidupkan suasana dan minat belajar anak. Terlihat anak antusias sekali dalam bernyanyi. Ada yang berebut minta duluan dan tidak sabaran untuk menunggu giliran. Kebanyakan masih belum bisa bernyanyi sesuai nada dengan tepat. Refleksi Siklus I (satu) hari kedua. nampak bahwa proses pembelajaran berdasarkan analisis peneliti berjalan lancar dan baik, masih ada 15 anak yang kemampuan bernyanyinya masih kurang. masih banyak anak yang senang memegang dan melihat-lihat alat musik Buret. Sehingga disimpulkan pada pertemuan yang kedua (2) pada siklus yang pertama (I) ini sudah ada perubahan, anak mempunyai kemampuan kemampuan anak cukup meningkat menjadi 4 anak (20\%) dan masih 15 anak (75\%) yang belum mulai berkembang.

Dari hasil pengamatan guru terhadap proses kegiatan belajar mengajar tentang bernyanyi ternyata dalam bernyanyi sesuai nada dengan menggunakan alat musik Buret dapat menghidupkan suasana 
minat belajar anak. Terlihat anak antusias sekali dalam bernyanyi ada yang berebut minta duluan dan tidak sabaran menunggu giliran. Dan kebanyakan masih tertarik untuk memegang alat musik Buret. Hasil refleksi proses pembelajaran berdasarkan analisis peneliti berjalan lancar dan baik, serta kembali menunjukan perubahan dimana jumlah anak dengan kemampuan cukup meningkat 5 anak (20\%) dan masih 14 anak (70\%) yang belum berkembang. Pertemuan ketiga ini merupakan akhir dari siklus satu sehingga secara keseluruhan perubahan pada siklus I dapat dilihat pada diagram 2 seperti berikut.

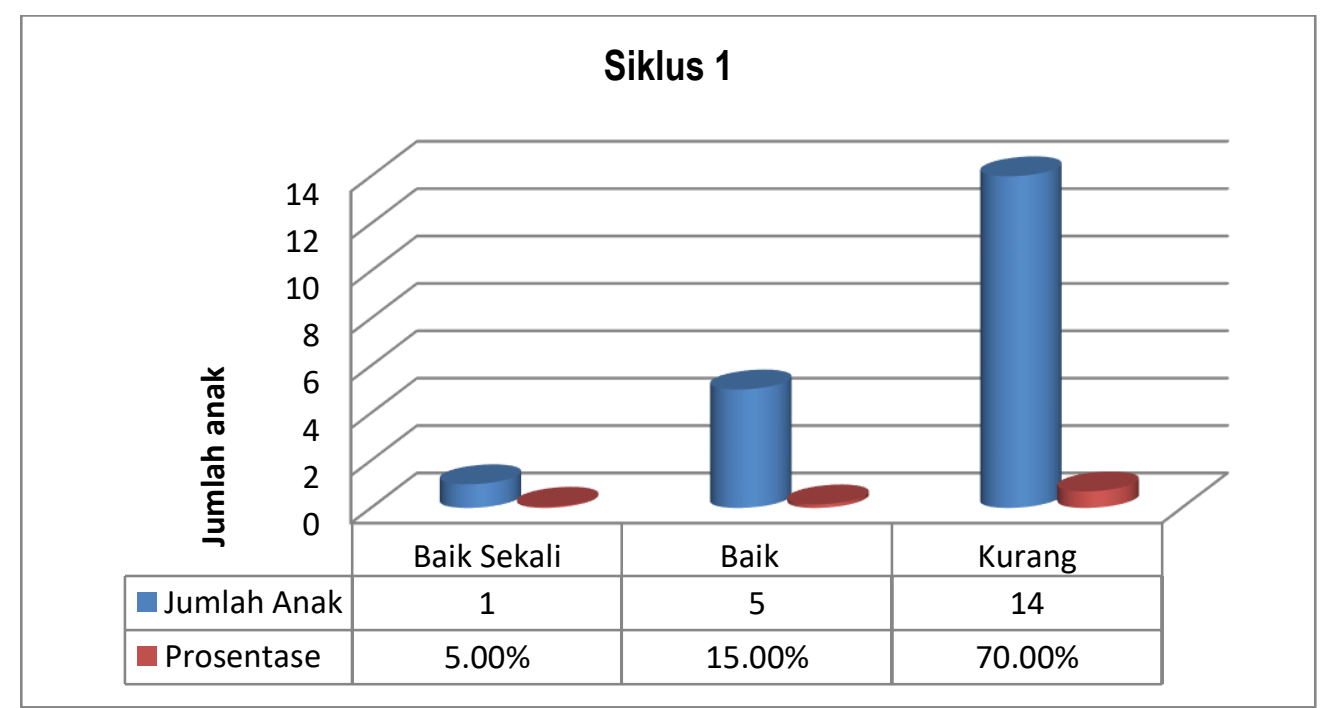

Diagram 2. Kondisi Kemampuan Bernyanyi Sesuai Nada pada Akhir Siklus I

\section{Siklus II}

Pada siklus kedua ini perbaika yang dilakukan ialah memberikan kesempatan anak untuk mencoba alat peraga buret. Dari hasil pengamatan guru terhadap proses kegiatan belajar mengajar tentang bernyanyi sesuai nada, ternyata dapat menghidupkan suasana dan minat belajar anak. Sehingga proses belajar mengajar, lancar, anak antusias sekali dalam bernyanyi sesuai nada. Refleksi Siklus II (dua) hari pertama menunjukan pembelajaran masih belum maksimal, meskipun demikian pada pertemuan pertama (1) pada siklus yang kedua (II) ini sudah ada perubahan, dimana siswa yang berkembang seperti harapan ada 6 anak (30\%) dan anak yang belum berkembang menyisakan 13 anak (65\%).

Perbaikan dilakukan pada pertemuan kedua, dimana guru tidak memberikan arahan namun siswa langsung mencoba. Dari hasil observasi guru terhadap oses pembelajaran pada pertemuan yang kedua (2) pada siklus yang kedua (2) ini anak-anak dalam bernyanyi sudah banyak yang bisa. Terbukti dari 20 anak yang ada, anak yang kemampuan bernyanyinya melebihi dari harapan peneliti yaitu ada 2 anak yang kalau di presentasi ada $10 \%$ dan anak yang kemampuannya sesuai dengan harapan ada 7 anak yang kalu di presentasi $35 \%$, dan anak yang belum berhasil ada 11 yaitu $55 \%$.

Perkembangan signifikan tersebut diteruskan pada pertemuan ketiga. Refleksi Siklus II (dua) hari ke tiga, dari hasil observasi pada kegiatan bernyanyi dengan menggunakan alat musik Buret, telah disimpulkan bahwa) pertemuan yang tiga ini telah berhasil, walaupun masih ada 5 anak yang kemampuan bernyanyinya masih kurang. Jadi hasilnya siklus kedua ini ada 13 anak yang kalau di presentasi ada $65 \%$ anak yang kemampuannya sesuai dengan harapan. ada 2 anak yang kalau di presentasi $10 \%$ yang kemampuannya melebihi indikator, dan anak yang belum berhasil ada 5 kalau di presentase yaitu ada $25 \%$. Pertemuan ketiga ini merupakan ahir dari siklus II sehingga hasil akhirnya dapat dilamati pada digram 3 serta pergerakanya secara keseluruhan dapat dilihat pada diagram 4 berikut. 


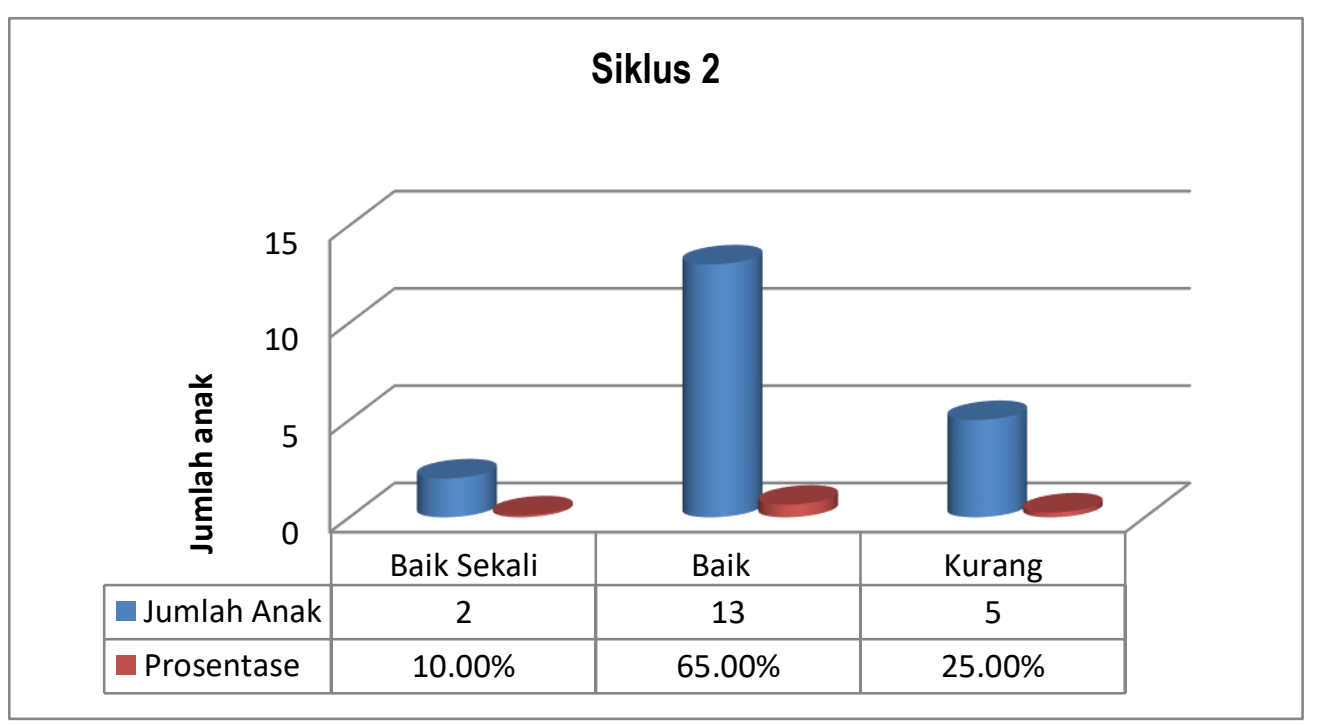

Diagram 3. Kondisi Kemampuan Bernyanyi Sesuai Nada pada Akhir Siklus II

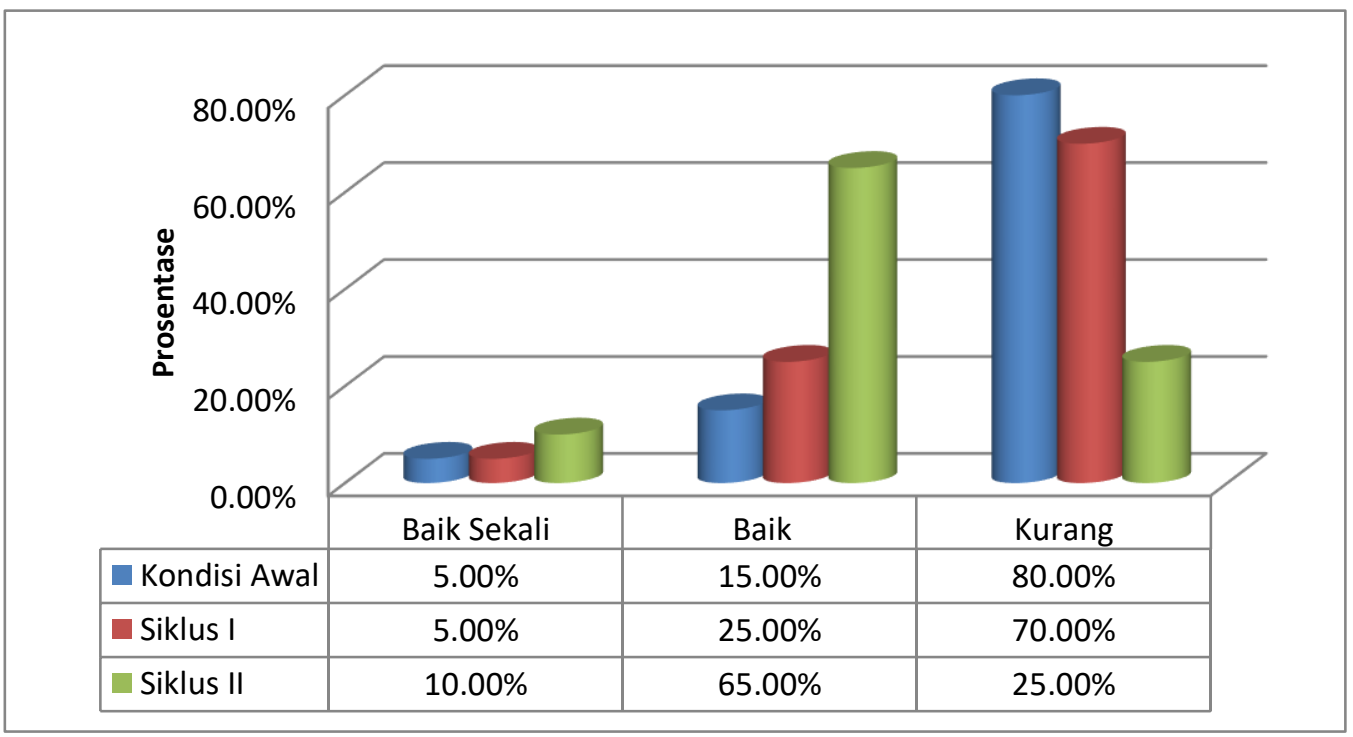

Diagram 4. Grafik Perbandingan Kondisi Awal, Siklus I dan Siklus II 


\section{KESIMPULAN DAN SARAN}

Setelah melalui pembelajaran bernyanyi sesuai nada dengan menggunakan alat music Buret, gairah belajar anak meningkat, suasana belajar menjadi lebih hidup keaktifan anak pun meningkat dan kemampuan bernyanyi sesuai nada berhasil, sehingga hasil belajarnya juga meningkat dalam bernyanyi sesuai nada dengan menggunakan alat musik Buret.

Pembelajaran bernyanyi sesuai nada dengan menggunakan alat musik Buret membuat anak aktif, motifatif, kreatif dan menyenangkan sehingga pembelajaran bermakna. Buret adalah alternatif alat musik yang dapat membantu mengatasi kejenuhan anak di dalam kelas, bila dilaksanakan dengan rencana yang matang dapat meningkatkan mutu pendidikan.

Dari hasil kegiatan tersebut diharapkan dapat dimanfaatkan dan menjadi inspirasi yang dapat dikembangkan oleh teman-teman guru TK yang akan berkreasi, dan inofatif dalam pembelajaran, karena konsep dan aplikasinya sudah penulis paparkan dengan jelas tentang.

Pembahasan bernyanyi sesuai nada dengan menggunakan alat musik Buret, didesain untuk mengatasi kejenuhan anak dikelas, mengembangkan kreatifitas, tanggungjawab, kemandirian pada anak dan hendaknya kita jangan merasa sulit dahulu sebelum di coba atau lakukan.

\section{DAFTAR PUSTAKA}

Ali, N. R., Erviana, Y., Jazariyah, Fadlilah, U., Hijriyani, Y. S., Pudjiastuti, A, Ulfa, R. I. (2016). Perkembangan \& Alat Permainan Edukatif anak Usia Dini. Yogykarta: Editie Pustaka.

Anitah, S. (2008). Meda Pembelajaran. Surakarta: UNS Press

Fadhlullah, H. (2012). Dunya Al-Tifl: Dunia Anak, Memahami Perasaan dan Pikiran Anak Anda. Terjemah: Najib Husain Al-Idrus. Bogor: Cahaya

Hildayani, R. (2009). Psikologi Perkembangan Anak. Jakarta: Universitas Terbuka.

Hurlock, E. B. (1995). Psikologi Perkembangan, Suatu Pendekatan Sepanjang Rentang Kehidupan: Edisi Kelima. Jakarta: Erlangga

Kemendikbud. (2015). Pedoman Penyusunan Kurikulum Tingkat Satuan Pendidikan (KTSP) Pendidikan Anak Usia Dini. Jakarta: Direktorat Pembinaan PAUD Kementerian Pendidikan dan Kebudayaan.

Kemendiknas. (2010). Peraturan Menteri Pendidikan Nasional Tentang Standar Pendidikan Anak Usia Dini. Jakarta: Direktorat Pendidikan Anak Usia Dini Kementerian Pendidkan Nasional.

Pratisti, W. D. (2008). Psikologi Anak Usia Dini. Jakarta: PT. Indeks.

Suyadi. (2010). Psikologi Belajar PAUD. Yogyakarta: Pedagogia.

Yamin, M., \& Sanan, J. S. (2013). Panduan PAUD. Ciputat: Refeensi.

Depdiknas (2004) Pembuatan dan Pemanfaatan alat peraga di TK. Jakarta: Direktorat Pendidikan Anak Usia Dini

Depdiknas (2006) Pedoman Pembuatan dan Pemanfaatan Alat Peraga di TK. Jakarta: Direktorat Pendidikan Anak Usia Dini 
Pekerti, W. dkk. (2010). Metode Pengembangan Seni Jakarta: Universitas Terbuka

Raharjo, S. (2006). Strategi Pembelajaran Musik Anak Usia Dini (TK \& SD). Jakarta: Aneka 